\title{
STRATEGI KAMPANYE MODEL BLUSUKAN JOKO WIDODO DALAM PEMENANGAN PEMILIHAN UMUM KEPALA DAERAH KOTA JAKARTA TAHUN 2012 (STUDI KASUS DI KECAMATAN KEMAYORAN, JAKARTA PUSAT)
}

\author{
Aryati Anggalia*), Efriza \\ Alumni Sarjana Ilmu Politik di Sekolah Tinggi Ilmu Pemerintahan Abdi Negara (STIP-AN), \\ *) email: anggaliia@gmail.com
}

Paper Accepted: 21 Juni 2020 Paper Reviewed: 22-29 Juni 2020 Paper Edited: 01-17 Juli 2020 Paper Approved: 28 Juli 2020

\begin{abstract}
ABSTRAK
Penelitian ini dilakukan untuk mengetahui kinerja Jokowi dengan melakukan kerja Blusukan menemui rakyatnya, yang dianggap memperoleh respons positif dari publik, sehingga dijadikan sebagai strategi kampanye blusukan Jokowi dalam upaya pemenangan Pilkada DKI Jakarta tahun 2012 lalu dan untuk mengetahui apa saja faktor-faktor positif dan negatif dari strategi kampanye blusukan Jokowi tersebut. Dari hasil penelitian ini dihasilkan bahwa kedekatan Jokowi sebagai pemimpin dengan masyarakat melalui gaya blusukannya, inilah yang membuat namanya melesat dan hal itu menjadikan gaya blusukannya sebagai bagian dari kampanyenya untuk menjelaskan program kerja yang akan ditawarkan ketika terpilih di Pilkada DKI Jakarta 2012 lalu. Blusukan yang telah menjadi strategi kampanye Jokowi terbukti berhasil dengan terpilihnya Jokowi-Ahok di Pilkada DKI Jakarta 2012 lalu, meski pasangan Jokowi-Ahok ditengarai akan kalah dalam Pilkada, namun realitasnya pasangan ini memenangkan Pilkada DKI Jakarta berdasarkan gaya blusukannya dengan cara menawarkan program kerja melalui komunikasi langsung dengan masyarakat/pemilih.
\end{abstract}

Kata Kunci: Pilkada, Blusukan, Kampanye

\section{PENDAHULUAN}

Pada Pemilihan Kepala Daerah (Pilkada) DKI Jakarta (2012) lalu, ada perkembangan yang menarik tentang kepemimpinan di Indonesia. Wali Kota Solo, Joko Widodo tibatiba menyeruak menjadi tokoh populer yang merakyat, sederhana, dan terkesan bekerja secara tulus. Joko Widodo atau akrab disapa Jokowi menjadi fenomena baru, saat menjadi penantang petahana Fauzi Bowo (Foke) maju sebagai calon Gubernur DKI Jakarta.

Jokowi sebagai fenomena pemimpin yang mendahulukan bekerja daripada berbicara yang akhirnya justru popularitasnya melesat, mulai diperhitungkan hingga dikancah perpolitikan nasional. Jokowi tak pernah bersolek dengan beriklan untuk mencitrakan penampilannya, ia hanya justru fokusnya bekerja dan bekerja untuk rakyat kala itu menjadi Walikota.

Keberhasilannya dalam memimpin, membuat namanya masuk dan memperoleh kenaikan bahkan memperoleh tiga besar dalam berbagai Polling menjelang Pilkada DKI Jakarta 2012 lalu. Figur Jokowi kian menarik bagi masyarakat, karena kepemimpinan Jokowi dianggap sebagai pemimpin yang mengusung kesetaraan, inklusif merangkul banyak kalangan, pluralis, dan menghargai kemajemukan etnis. Yang semakin membuatnya kian diharapkan oleh masyarakat Jakarta adalah, kemampuannya membangun konektivitas sosial, seperti melalui kebiasaannya "blusukan" ke 
kampung-kampung, (Henry Subiakto dan Rachmah Ida, 2014: 42).

Jokowi populer tidak saja dalam lingkup lokal, juga di kancah nasional. Bahkan, dunia internasional mengakui kualitas kepemimpinan Jokowi. Mudah saja untuk menilai kualitas kepemimpinan Jokowi, (Andrie Indradie, 2013: 123). Lihat saja, kecenderungannya untuk lebih sering menyapa ke bawah, dan melayani yang memang seharusnya dilayani, yakni rakyat. Bahkan, sikap merakyat yang paling orisinal adalah milik Jokowi, ia lebih banyak berkantor di tengah masyarakat daripada di gedung. Menurut penuturannya, ia hanya berkantor 1 jam saja, selebihnya ia mendatangi tempattempat di mana warga kota berkumpul. Ia rajin mengunjungi warga di kampung-kampung, termasuk mereka yang mendiami pemukiman bantaran sungai, (Sudarsono, 2012: 2-3).

Sebagai pemimpin kala itu, ia juga sering berdialog dengan para Pedagang Kaki Lima (PKL), dan pedagang di pasar. Ia tak segan menyambangi tukang becak dan kelompok terpinggirkan lainnya. Belum lagi aktivitasnya dalam berbagai forum dialog warga yang difasilitasinya, (Sudarsono, 2012: 3). Itu semua dilakukannya demi menyerap aspirasi dan keluhan yang berkembang dalam masyarakat. Karena seringnya ia berada di tengah masyarakat, ia menjadi paham akan masalah yang mendera masyarakatnya, memahami kebijakan apa yang lebih tepat diimplementasikan untuk menyelesaikan permasalahan masyarakat.

Jokowi memiliki gaya kepemimpinannya yang pragmatis dan membumi. Turun langsung ke lapangan dan melihat langsung permasalahan yang ada untuk menemukan solusi yang tepat. Menemui langsung warga dan mendengar keluh-kesah warga dan mendekati warga bila akan melancarkan suatu program. Melepaskan semua yang berbau protokoler sebagai pejabat politik dan membaur dengan rakyat, dalam posisi komunikasi yang setara, (Sudarsono, 2012: 17).

Gaya kepemimpinan Jokowi yang bersifat baru di pemerintahan Indonesia ini memang menuai pujian di luar negeri dan memperoleh citra positif dari masyarakat. Jokowi dengan prinsip politiknya 'memanusiakan manusia' menganggap warga yang paling tahu permasalahannya masing-masing, dan pemerintah hanya menjadi pelayan, pengawal, sekaligus pemimpin warga untuk menjadi lebih baik. Blusukan Jokowi (secara tidak langsung) adalah program kebijakan Jokowi untuk melibatkan warga dalam menentukan kebijakan atau tindakan penyelesaian, sehingga ketika kebijakan itu ditetapkan, warga akan menerima dengan kesadaran, (Sudarsono, 2012: 18).

Waktu dan energi Joko Widodo bisa habis hanya untuk blusukan. Joko Widodo menjelaskan bahwa turun ke lapangan yang dilakukannya bukanlah berarti hanya menemui warga serta melihat kondisi perkampungan kumuh, akan tetapi, juga untuk mengontrol lapangan, memantau pelaksanaan proyek dan program kerja. Blusukan merupakan cara Joko Widodo untuk melibatkan partisipasi masyarakat dalam pembangunan kota sekaligus pengejawantahan dari demokrasi sejati, karena, setiap saat rakyat dihadirkan dalam politik. Bukan hanya pada saat pemilu berlangsung, (Jurnal Politik, 2017).

Berkat prestasi dan kepopuleran yang diraih Jokowi selama menjadi Wali kota Solo dalam dua periode, Jusuf Kalla secara pribadi meminta Jokowi untuk mencalonkan diri sebagai Gubernur DKI Jakarta pada Pilkada DKI Tahun 2012 lalu. Jusuf Kalla bahkan bersedia membicarakan dengan Megawati Soekarnoputri selaku Ketua Umum Partai Demokrasi Indonesia Perjuangan (PDI Perjuangan) yang merupakan partainya Jokowi untuk mencalonkan Jokowi sebagai Gubernur DKI Jakarta. Di samping Jusuf Kalla, Prabowo Subianto (Ketua Partai Gerindra) juga melobi PDI Perjuangan agar bersedia mendukung sebagai calon gubernur karena membutuhkan 9 kursi lagi untuk mengajukan calon gubernur berpasangan dengan Basuki Tjahaja Purnama (biasa disapa Ahok), calon dari Partai Gerindra. Basuki Tjahaja Purnama adalah anggota Dewan Perwakilan Rakyat (DPR) dari Partai Golkar, dan pindah ke Gerindra karena Golkar telah sepakat mendukung Alex Noerdin sebagai Calon Gubernur. Megawati dan PDI Perjuangan sendiri sebenarnya sudah hampir memberikan dukungan kepada Fauzi Bowo (calon petahana), (Sudarsono, 2012: 27).

Akhirnya, PDI Perjuangan bersama Partai Gerindra mencalonkan Pasangan Jokowi dan Basuki Tjahaja Purnama. Jokowi dan Ahok sepasang pemimpin muda yang terbilang berani, bahkan cenderung nekat, karena maju sebagai calon gubernur-calon wakil gubernur DKI Jakarta. Sebuah daerah yang mereka sendiri tidak mengetahui kondisi yang sebenarnya mengenai tempat di mana mereka akan menjadi seorang pemimpin nantinya. Keduanya hanya bermodal semangat dan mandat dari masingmasing (PDI Perjuangan dan Gerindra), mencoba bersaing dengan Fauzi BowoNachrowi Ramli, pasangan Hendardji SoepandiAhmad Riza Patria, pasangan Hidayat Nurwahid-Didiek J. Rachbini, pasangan Faisal 
Basri-Biem Benjamin, dan pasangan Alex Noerdin-Nono Sampono, yang semuanya sudah mengenal DKI Jakarta, (Sudarsono, 2012: 28).

Di luar dugaan, pasangan Jokowi-Ahok yang tidak diunggulkan ini, dalam berbagai hasil survei antara lain, hasil survei kerjasama Lembaga Penelitian Pendidikan, dan Penerangan Ekonomi dan Sosial (LP3ES), Media Nusantara Citra Tbk (MNC) Riset, dan Prisma, menyimpulkan hasil yang digelar sepuluh hari sebelum pemungutan suara, bahwa pemilihan berlangsung dua putaran. Babak kedua antara Fauzi Bowo-Nachrowi Ramli versus Jokowi-Ahok. Perolehan dua pasangan itu berdasarkan hasil survei, sangat tipis. Fauzi Bowo-Nachrowi Ramli unggul dengan 24,5 persen. Sementara Jokowi-Ahok menguntit dengan perolehan 22,7 persen, (Sudarsono, 2012: 31).

Pasangan Jokowi dan Ahok yang tak diunggulkan ini, ternyata secara mengejutkan, berhasil memenangkan pemilihan gubernur DKI Jakarta 2012 lalu, dengan hasil perhitungan suara yang ditetapkan Komisi Pemilihan Umum Daerah (KPUD) DKI Jakarta pada 29 September 2012, pasangan Jokowi-Ahok meraih 53,82 persen suara dan pasangan Fauzi BowoNachrowi Ramli meraih 46,18 persen dari suara yang sah. KPUD DKI Jakarta menetapkan pasangan Jokowi-Ahok sebagai gubernur dan wakil gubernur DKI yang baru masa bakti 20122017, (Sudarsono, 2012: 38).

Kemenangan Pasangan Jokowi-Ahok yang tak diunggulkan ini, ternyata memiliki strategi tersendiri dalam menyiasati hasil survei. Gaya berkampanye Jokowi yang menekankan pendekatan langsung kepada masyarakat dengan mendatangi mereka langsung daripada mengumpulkan orang di lapangan, menghindari pemasangan spanduk, poster, stiker, dan baliho di taman kota atau jalan karena menurutnya dapat mengotori kota malah sulit mendapatkan simpati dari masyarakat luas, (Sudarsono, 2012: 31).

Gaya blusukan Jokowi untuk bertemu dengan warga atau langsung turun ke bawah menyelesaikan masalah di masyarakat mendapatkan apresiasi positif dari sebagian besar masyarakat Jakarta. Tak pelak, gaya Jokowi menjadi buah bibir masyarakat maupun media massa. Sebagian besar menyakini bahwa dengan cara blusukannya tersebut melalui menawarkan program-program kerjanya (berupa Kartu Jakarta Pintar dan Kartu Jakarta Sehat) membuat Jokowi diterima dan didukung sepenuhnya, karena diyakini program yang ditawarkannya secara langsung itu dianggap dapat mengatasi permasalahan-permasalahan yang dialami warga yang berimplikasi pada kepercayaan warga terhadap figur Jokowi, (unikom.ac.id).

Blusukan Jokowi dimaknai menjadi karakter kepemimpinannya dan sebagai simbol kegiatan yang pro rakyat karena di dalamnya terdapat interaksi langsung antara pemimpin dan rakyat yang dipimpinnya. Aktifitas blusukan ini akhirnya menjadi suatu aktifitas sakral dan wajib dilakukan oleh pemimpin. Rakyat yang bosan dengan arogansi kepemimpinan yang ada di Indonesia saat ini menjadi suka dan nyaman dengan aktifitas blusukan ala Jokowi, (unikom.ac.id).

Cara yang dilakukan oleh Jokowi ini, telah dipraktekkannya selama perjalanan karir politik Jokowi di partai berlambang moncong putih itu. Yang jelas, Jokowi menginginkan politik yang beretika, ketika melakukan kampanye untuk bertarung memperebutkan misalnya jabatan wali kota Solo, Jokowi tak mengerahkan dana besar-besaran. Ia tak berkampanye di media massa maupun pasang spanduk besar-besaran. Ia justru memilih kampanye door to door di masyarakat, (Sudarsono, 2012: 23-24).

Hal serupa juga dilakukannya ketika ia berhasil memenangkan Pilkada DKI Jakarta. Ia rajin mengunjungi wong cilik di kampungkampung kumuh, misalnya, Jakarta Pusat dengan dua lokasi titiknya (Kelurahan Cempaka Baru dan Kelurahan Serdang) menjadi lokasi tempat Jokowi menemui masyarakat dalam Pilkada DKI Jakarta 2012 lalu.

Saat Jokowi melakukan kampanye menemui masyarakat, di Kelurahan Cempaka Baru, Kemayoran, Jakarta Pusat, Senin 25 Juni 2012. Ia masuk gang-gang sempit selebar 3 meter di kawasan permukiman padat di Gang RT 7 Nomor 1 di Kelurahan Cempaka Baru, Kemayoran, Jakarta Pusat. Di gang sempit itu Jokowi terhenti di sejumlah rumah penduduk dan berdialog dengan warga, sambil menjelaskan program unggulannya, Kartu Sehat dan Kartu Pintar. Tak pelak, gang padat itu pun penuh sesak dengan orang yang berniat melihatnya berkampanye, (tempo.co).

Jadi guna meraih dukungan pada putaran kedua pilkada DKI Jakarta, Jokowi mengandalkan partisipasi masyarakat dan tidak akan mengobral soal janji-janji politik. Sebab, bagi Jokowi, masyarakat sudah bosan dikasih janji-janji politik, jadi sesuai dengan konsep yang telah dijalankan oleh Jokowi pada putaran pertama, maka kampanye-kampanyenya di putaran kedua tetap jalan-jalan mengunjungi pasar dan rumah penduduk, (viva.co.id).

Kegiatan blusukan Jokowi ini juga menyebabkan Jokowi menjadi "media darling," 
kekuatan dahsyat melalui popularitas gaya blusukannya dapat menghadirkan manfaat untuk dijadikan isu kampanye. Meski Jokowi telah menjadi media darling, namun sikapnya itu tidak serta-merta hanya ditunjukkan di depan media massa semata. Gaya berpolitik Jokowi ini bukanlah hasil pencitraan, tetapi memang merupakan karakter dirinya sendiri bahwa Jokowi adalah simbol pemimpin, yang bersahaja, apa adanya, tidak dibuat-buat, dan tanpa dipenuhi simbol negara yang kaku, menjadikannya seperti "tidak ada jarak" antara yang dipimpin dan yang memimpin, (Retno Wulandari, 2014: xiv).

\section{Perumusan Permasalahan}

Berdasarkan uraian di atas, menyembulkan pertanyaan ke permukaan yang sekaligus terkait dengan studi kasus pada wilayah yang diteli dalam penelitian ini, yakni: Bagaimana kinerja Jokowi dengan cara Blusukan menjadi suatu strategi kampanye dalam Kemenangan Pasangan Jokowi-Ahok pada Pemilihan Kepala Daerah DKI Jakarta 2012 di Kemayoran, Jakarta Pusat? Dan, Apa saja faktor-faktor positif dan negatif dari blusukan sebagai strategi kampanye kemenangan pasangan Jokowi-Ahok pada Pemilihan Kepala Daerah DKI Jakarta 2012 di Kemayoran, Jakarta Pusat?

\section{METODE PENELITIAN}

Penelitian ini menggunakan pendekatan penelitian kualitatif. Pendekatan kualitatif menunjukkan bahwa pelaksanaan penelitian ini terjadi secara alamiah, apa adanya, dalam situasi normal yang tidak dimanipulasi keadaan dan kondisinya, menekankan pada deskripsi secara alami, (Suharsimi Arikunto, 2012: 11-12). Dalam melakukan prosedur pengumpulan data bahwa sumber data yang digunakan dalam penelitian ini adalah melalui dua teknik yakni: pertama, data yang bersifat primer adalah data yang diperoleh langsung dari informan berdasarkan hasil wawancara. Pada tahap ini, penulis mewawancarai informan-informan yang menjadi sumber data penelitian (menggunakan pedoman wawancara yang telah disiapkan sebelumnya, dengan beberapa pertanyaan yang bersifat terbuka). Sedangkan, data sekunder adalah data yang diperoleh dari teknik pengumpulan data yang menunjang data primer yang bersumber dari buku, jurnal, dokumentasi dan media ataupun hasil riset yang berhubungan dengan penelitian ini khususnya terhadap strategi kampanye (penerapan komunikasi kampanye secara blusukan) terhadap pasangan calon gubernur dan wakil gubernur Jokowi-Ahok di Kemayoran, Jakarta Pusat.

\section{PEMBAHASAN}

\section{Konsep Marketing Politik dan Blusukan}

Penggunaan metode marketing dalam bidang politik dikenal sebagai marketing politik (political marketing). Dalam marketing politik yang ditekankan adalah penggunaan pendekatan dan metode marketing untuk membantu politisi dan partai politik agar lebih efisien dan efektif dalam membangun hubungan dua arah dengan konstituen dan masyarakat. Hubungan ini diartikan secara luas, dari kontak fisik selama periode kampanye sampai dengan komunikasi tidak langsung melalui pemberitaan di media massa, (Firmanzah, 2007: 141).

Marketing politik merupakan aktivitas yang dilakukan oleh partai politik dan kontestan individu dalam merancang isu-isu yang akan dilempar ke masyarakat, mengomunikasikan solusi yang hendak diterapkan ketika berkuasa, menyampaikan ideologi partai dan kontrol sosial terhadap partai atau individu yang berkuasa. Meski sebenarnya fungsi dari marketing politik tidak semata untuk memperkenalkan partai politik dan kandidat, tetapi juga melakukan pendidikan politik. Sebab, berbagai informasi yang disampaikan para tim sukses lewat media merupakan informasi baru bagi masyarakat, sehingga mereka bisa lebih melakukan studi banding antar berbagai partai dan kandidat yang harus dipilih. Berbagai upaya yang dilakukan untuk melakukan marketing politik, seperti melibatkan banyak kader dan masyarakat dalam prosesnya merupakan pendidikan politik sebab di situ ada upaya untuk melakukan partisipasi politik secara aktif.

Melalui marketing politik kini masyarakat menjadi lebih mudah mengakses peserta pemilu karena para kandidat dan partai politik justru secara agresif mendekati masyarakat dan menjelaskan tentang dirinya dan lembaganya. Hal ini belum tentu akan dirasakan dikala proses demokrasi belum diwarnai marketing politik sehingga demokrasi cenderung tertutup, (Roni Tabroni, 2014: 7-8).

Perlu ditegaskan di sini bahwa marketing politik tidak menentukan kemenangan sebuah partai politik atau kandidat politisi, atau kandidat presiden. Marketing poltiik hanyalah sebuah metode dan peralatan bagi partai politik atau calon politisi atau calon presiden untuk melakukan pendekatan kepada publik. Sistematisasi pendekatan yang dilakukan 
kandidat perlu dilakukan mengingat selalu terdapat keterbatasan sumberdaya yang dimiliki setiap kandidat. Apakah setelah menerapkan marketing poltiik maka secara otomatis kandidat atau partai politik akan ke luar sebagai pemenang? Jawabannya adalah tidak. Apalagi kalau setiap orang dan partai politik juga menggunakan marketing politik. Maka marketing politik menjadi keharusan (necessary-condition) dan bukan lagi sebagai penentu (determinant factor). Siapa yang menang dan kalah akan sangat ditentukan oleh kualitas penerapan marketing politik dan bukan hanya sekadar ikut-ikutan saja (mimetic), (Firmanzah, 2008: XL-XLI).

Marketing Politik seperti dijelaskan oleh Adman Nursal bahwa, berdasarkan realitasnya bahwa marketing politik digunakan untuk menghasilkan meanings (makna). Political marketing adalah serangkaian aktivitas terencana, strategis, tetapi juga taktis, berdimensi jangka panjang dan jangka pendek, untuk menyebarkan makna politik kepada para pemilih. Tujuannya membentuk dan menanamkan harapan, sikap, keyakinan, orientasi dan perilaku pemilih. Perilaku pemilih yang diharapkan adalah ekspresi mendukung dan berbagai dimensinya, khususnya menjatuhkan pada partai atau kandidat tertentu, (Adman Nursal, 2004: 23).

Oleh karena itu, layaknya produk yang hendak dijual kepada pangsa pasar, partai politik dan para kandidatnya juga perlu dibranding serta ditentukan positioning-nya (posisi pasar) dalam benak segmen (segmenting) mereka masing-masing, (Umaimah Wahid, 2016: 206-207). Untuk melakukan itu dilakukan dengan menerapkan riset politik untuk memperoleh landasan umum pemilihan antara lain mengenai harapan dan perilaku pemilih terhadap sejumlah elemen yang terdapat dalam 4P (produk, promosi, price (harga), dan penempatan) bauran produk politik.

Menurut Firmanzah, proses pemasaran politik dapat menggunakan 4P bauran pemasaran, antara lain: (1). Produk (product), berupa partai, kandidat dan gagasan-gagasan partai yang akan disampaikan kepada konstituen. Produk berisi konsep dan identitas ideologi yang berkontribusi dalam pembentukan sebuah produk politik, pada masa lalu dan sekarang. Contoh, produk politik adalah kandidat atau calon dalam pemilu dan programprogram yang dicanangkan. (2). Promosi (promotion), dengan cara upaya periklanan, kehumasan, dan promosi untuk sebuah partai yang dibaurkan sedemikian rupa sesuai dengan kebutuhan masyarakat. Dalam proses kampanye, promosi dilakukan secara maksimal untuk memperkenalkan produk sekaligus menguji penerimaan masyarakat terhadap kandidat. Promosi dilakukan dalam beragam bentuk dan media massa cenderung menjadi pilihan utama para kandidat dalam kampanye politik sekarang ini. Oleh karena itu, kehadiran media massa tidak bisa diabaikan meskipun sebagian kandidat menyatakan tidak akan menggunakan iklan melalui media massa atau media ruang. (3). Harga (price), dalam hal ini mencakup berbagai hal, seperti ekonomi, psikologi, sampai citra nasional. Harga ekonomi mencakup semua biaya yang dikeluar partai selama periode kampanye. Harga psikologis mengacu pada harga persepsi psikologis, misalnya pemilih merasa nyaman dengan latar belakang etnis, agama, pendidikan. Sedangkan harga citra berkaitan dengan apakah pemilih merasa kandidat tersebut dapat memberikan citra positif dan dapat menjadi kebanggan negara. Kampanye dengan menggunakan media, seperti media massa, new media, media sosial, maupun media luar ruang, sudah pasti membutuhkan biaya besar. Harga dan tataran praktis adalah jumlah biaya atau modal uang yang diperlukan untuk kampanye seorang kandidat. Sedangkan harga ideologi, nilai, dan sosial budaya adalah penerimaan serta kredibilitas kandidat; apakah kandidat layak dan mampu menjadi representasi wilayah atau organisasi yang mencalonkan kandidat tersebut; dan (4). Penempatan (place), berkaitan dengan cara hadir atau distribusi sebuah partai atau kandidat dan kemampuannya dalam berkomunikasi dengan para pemilih. Artinya, sebuah partai atau kandidat harus dapat memetakan struktur dan karakteristik masyarakat, secara geografis maupun demografis. Konsep ini merupakan strategi pencapaian khalayak berdasarkan relung khalayak yang potensial untuk memilih kandidat, meski kenyataannya, tiap-tiap partai politik dan kandidatnya telah memunyai relung wilayah dan pemilih tersendiri, (Firmanzah, 2008: 203-204).

Bahwa $4 \mathrm{P}$ pemasaran dalam dunia politik menjadikan pemasaran politik bukan hanya masalah iklan, melainkan lebih komprehensif. Pemasaran politik juga menyangkut cara institusi politik (partai politik) dalam mempromosikan produk politik, menyusun program publikasi kampanye, komunikasi politik, strategi segmentasi untuk memenuhi kebutuhan segmentasi lapisan masyarakat, dan perhitungan harga sebuah produk politik, (Umaimah Wahid, 2016: 208). 
Namun, perlu ditegaskan bahwa marketing politik jangan dipahami sebagai konsep untuk menjual partai politik atau calon kandidat ke pemilih, namun sebuah konsep yang menawarkan bagaimana sebuah partai politik atau kontestan bisa membuat program yang berhubungan dengan permasalahan aktual. Marketing politik adalah konsep pemasaran yang harus dilakukan terus menerus oleh sebuah partai politik atau kontestan dalam membangun kepercayaan dan image publik. Membangun kepercayaan dan image ini hanyalah bisa dilakukan melalui hubungan jangka panjang, tidak hanya pada masa kampanye semata.

Marketing politik harus dilihat secara komprehensif, bahwa pertama, marketing politik lebih daripada sekadar komunikasi politik. Kedua, marketing politik diaplikasikan dalam seluruh proses organisasi partai politik tidak hanya tentang kampanye politik tetapi juga sampai pada tahap bagaimana memformulasikan produk politik melalui pembangunan simbol, image, platfrom dan program yang ditawarkan. Ketiga, marketing politik menggunakan konsep marketing secara luas, tidak hanya terbatas pada teknik marketing, namun juga sampai strategi marketing, dari teknik publikasi, menawarkan ide dan program, dan desain produk sampai ke market intelligent serta pemprosesan informasi. Keempat, memahami marketing politik tidak hanya sekadar politik, tetapi perlu menguasai pula pemahaman secara sosiologi dan psikologi. Misalnya, produk politik merupakan fungsi dari pemahaman sosiologis mengenai simbol dan identitas, sedangkan faktor psikologisnya adalah kedekatan emosional dan karakter seorang pemimpin, sampai ke aspek rasionalitas platfrom partai. Terakhir, konsep marketing politik bisa diterapkan dalam berbagai situasi, misal, mulai dari pemilihan umum sampai ke proses lobi di parlemen.

Dengan demikian, sudah jelas apakah yang dimaksud dengan marketing politik di sini. Marketing politik bukan dimaksudkan untuk 'menjual' kontestan kepada publik, melainkan sebagai teknik untuk memelihara hubungan dengan publik agar tercipta hubungan dua arah yang langeng, antara pemimpin dan masyarakat, (Firmanzah, 2008: 166-167).

Sedangkan, yang perlu dipahami berikutnya adalah mengenai Blusukan yang dianggap sebagai kampanye politik dari pasangan Jokowi-Ahok. Blusukan yang dilakukan adalah upaya dalam melakukan jalinan komunikasi dua arah yang terbuka sehingga bisa melokalisir permasalahan yang ada. Untuk mewujudkan komunikasi dua arah ini, maka perlu dilakukan dengan cara kegiatan mengobrol dan berdiskusi secara lebih dekat, komunikasi ini dalam konsep Barat dikenal dengan "managing by walking around." Dalam perspektif lokal, masyarakat Jawa telah mengenalkan konsep komunikasi "blusukan," yaitu berkomunikasi face to face dengan mendatangi secara langsung publiknya. Ada kedekatan personal - tidak ada jarak fisik sehingga bisa mendekatkan jarak psikologi, dalam komunikasinya ini tentunya adanya komunikasi "sambung roso" (sambung rasa, dari hati ke hati) yang menimbulkan ikatan emosi (empati) yang kuat.

Komunikasi "blusukan" ini juga perwujudan adanya prinsip kebersamaan tanpa beda status "manunggaling kawula gusti," yang dalam perspektif Barat disebut "walking in the shoes of the public." Melalui blusukan, bisa melalui gethok tular(word of mouth communication) secara langsung informasi bisa didapatkan dan meminimalkan salah persepsi. Selain itu, blusukan juga bisa menyetop rumor yang memang tersebar cepat melalui gethok tular dari (mulut) orang ke (mulut) orang. Upaya gethok tular ini penting untuk menangkal rumor berdasarkan prinsip "lawanlah informasi dengan informasi, (ub.ac.id).

Blusukan menurut Mulyono dikutip A. Zulkarnain dan Syamsuddin Haris bahwa berasal dari kata blusuk yang artinya masuk ke dalam. Blusak-blusuk diartikan mlebu ing ngendi-ngendi, atau masuk ke mana-mana, adapun imbuhan akhiran, pada kata blusuk-an bermakna masuk ke, yakni kegiatan memasuki suatu tempat yang asing, tak lazim, tak biasa untuk menemukan atau mencari sesuatu, (Jurnal Politik, 2017).

Di samping itu, A. Zulkarnain dan Syamsuddin Haris dengan meminjam bahasa Reza A.A Wattimena bahwa, politik blusukan adalah politik kritis yang menolak tunduk patuh pada data statistik ciptaan para birokrat, dan berusaha sendiri mencari apa yang terjadi di lapangan. Dengan politik blusukan, para pemimpin politik dapat mengecek langsung, apakah keputusan yang telah ia buat dijalankan dengan baik atau tidak. Dari sudut pandangan metode berpikir ilmiah, cara ini disebut juga verifikasi, (Jurnal Politik, 2017).

\section{Jokowi dan Kepopuleran di Kota Solo}

Joko Widodo atau akrab disapa Jokowi yang saat itu menjabat sebagai walikota Solo tiba-tiba menyeruak menjadi tokoh populer yang merakyat, sederhana, dan terkesan bekerja secara tulus. Jokowi menjadi fenomena baru, saat mulai diperhitungkan menjadi penantang 
petahana Fauzi Bowo (Foke) untuk menjadi Gubernur DKI Jakarta.

Jokowi dianggap sebagai fenomena pemimpin yang mendahulukan bekerja daripada berbicara yang akhirnya justru popularitasnya melesat, mulai diperhitungkan hingga dikancah perpolitikan nasional. Jokowi tak pernah bersolek dengan beriklan untuk mencitrakan penampilannya, ia hanya justru fokusnya bekerja dan bekerja untuk rakyat kala itu untuk rakyatnya di Kota Solo.

Dari keberhasilannya di Kota Solo, namanya masuk dan memperoleh kenaikan popularitas bahkan memperoleh tiga besar dalam berbagai Polling menjelang Pilkada DKI Jakarta 2012 lalu. Figur Jokowi kian menarik bagi masyarakat, karena kepemimpinan Jokowi dianggap sebagai pemimpin yang mengusung kesetaraan, inklusif merangkul banyak kalangan, pluralis, dan menghargai kemajemukan etnis. Yang semakin membuatnya kian diharapkan oleh masyarakat Jakarta adalah, kemampuannya membangun konektivitas sosial, seperti melalui kebiasaannya "blusukan" ke kampung-kampung, (Henry Subiakto dan Rachmah Ida, 2014: 42).

Padahal saat masih menjabat walikota Solo, sosok Jokowi diasosiasikan dengan mobil Esemka sehingga muncul persepsi bahwa Jokowi siap membangun industri otomotif dalam negeri. Asosiasi ini kemudian berubah ketika Jokowi mulai diperhitungkan untuk mencalonkan diri sebagai Gubernur DKI menjadi pemimpin yang suka blusukan karena sering masuk ke tempat kumuh hingga ke gorong-gorong untuk mengecek dan mengetahui sesuatu, (Silih Agung Wasesa, 2018: 3).

Jadi dapat dikatakan bahwa sebagai wali kota Solo, Jokowi tak cuma populer di kalangan masyarakat kota Solo. Namun, nama Jokowi juga berkibar di kancah nasional. Bahkan, dunia internasional mengakui kualitas kepemimpinan Jokowi. Mudah saja untuk menilai kualitas kepemimpinan Jokowi, (Andrie Indradie, 2013: 123). Lihat saja, kecenderungannya untuk lebih sering menyapa ke bawah, dan melayani yang memang seharusnya dilayani, yakni rakyat, bahkan sikap merakyat yang paling orisinal adalah milik Jokowi, ia lebih banyak berkantor di tengah masyarakat dari pada di gedung. Menurut penuturannya, ia hanya berkantor 1 jam saja, selebihnya ia mendatangi tempattempat di mana warga kota berkumpul. Ia rajin mengunjungi warga di kampung-kampung, termasuk mereka yang mendiami pemukiman bantaran sungai, (Sudarsono, 2012: 2-3).

Ia juga sering berdialog dengan para Pedagang Kaki Lima (PKL), dan pedagang di pasar. Ia tak segan menyambangi tukang becak dan kelompok terpinggirkan lainnya. Belum lagi aktivitasnya dalam berbagai forum dialog warga yang difasilitasinya, (Sudarsono, 2012: 3). Itu semua dilakukannya demi menyerap aspirasi dan keluhan yang berkembang dalam masyarakat. Karena seringnya ia berada di tengah masyarakat, ia menjadi paham akan masalah yang mendera masyarakatnya, memahami kebijakan apa yang lebih tepat diimplementasikan untuk menyelesaikan permasalahan masyarakat.

Atas keberhasilannya di Kota Solo, Majalah Tempo memasukan Jokowi sebagai salah satu dari 10 tokoh tahun 2008, dari 427 kabupaten dan kota di tanah air. Dasar pertimbangan Tempo memilih Jokowi sebagaimana tercantum pada halaman situsnya tanggal 22 Desember 2008 adalah: "Sedikit Orang Baik di Republik yang Luas." Wali kota Solo Jokowi mendemonstrasikan bagaimana memanusiakan warganya. Ketika harus memindahkan pedagang kaki lima. Ia lebih dulu mengundang makan para pelaku sektor informal itu. Ia tak memilih jalan pintas: mengerahkan aparat untuk membakar lokasi. Setelah undangan makan yang ke-54, baru ia yakin pedagang siap dipindahkan. Acara pemindahan pun dilakukan secara meriah, lengkap dengan arak-arakan yang diramaikan pasukan keraton. Para pedagang gembira ria, mereka menyediakan tumpeng sendiri, (Nur Ibad Ms, 2015: 66).

Jokowi memiliki gaya kepemimpinannya yang pragmatis dan membumi. Turun langsung ke lapangan dan melihat langsung permasalahan yang ada untuk menemukan solusi yang tepat. Menemui langsung warga dan mendengar keluh kesah warga dan mendekati warga bila akan melancarkan suatu program. Melepaskan semua yang berbau protokoler sebagai pejabat politik dan membaur dengan rakyat, dalam posisi komunikasi yang setara, (Nur Ibad Ms, 2015: 17).

Gaya kepemimpinan Jokowi yang bersifat baru di pemerintahan Indonesia ini memang menuai pujian di luar negeri dan memperoleh citra positif dari masyarakat. Jokowi dengan prinsip politiknya 'memanusiakan manusia' menganggap warga yang paling tahu permasalahannya masing-masing, dan pemerintah hanya menjadi pelayan, pengawal, sekaligus pemimpin warga untuk menjadi lebih baik. Blusukan Jokowi (secara tidak langsung) adalah program kebijakan Jokowi untuk melibatkan warga dalam menentukan kebijakan atau tindakan penyelesaian, sehingga ketika 
kebijakan itu ditetapkan, warga akan menerima dengan kesadaran, (Nur Ibad Ms, 2015: 18).

Berkat prestasi dan kepopuleran yang diraih Jokowi selama menjadi Wali kota Solo dalam dua periode, Jusuf Kalla secara pribadi meminta Jokowi untuk mencalonkan diri sebagai Gubernur DKI Jakarta pada Pilkada DKI Tahun 2012 lalu. Jusuf Kalla bahkan bersedia membicarakan dengan Megawati Soekarnoputri selaku Ketua Umum Partai Demokrasi Indonesia Perjuangan (PDI Perjuangan) yang merupakan partainya Jokowi untuk mencalonkan Jokowi sebagai Gubernur DKI Jakarta. Di samping Jusuf Kalla, Prabowo Subianto (Ketua Partai Gerindra) juga melobi PDI Perjuangan agar bersedia mendukung sebagai calon gubernur karena membutuhkan 9 kursi lagi untuk mengajukan calon gubernur berpasangan dengan Basuki Tjahaja Purnama (biasa disapa Ahok), calon dari Partai Gerindra. Basuki Tjahaja Purnama adalah anggota DPR dari Partai Golkar, dan pindah ke Gerindra karena Golkar telah sepakat mendukung Alex Noerdin sebagai Calon Gubernur. Megawati dan PDI Perjuangan sendiri sebenarnya sudah hampir memberikan dukungan kepada Fauzi Bowo (calon petahana), (Nur Ibad Ms, 2015: 28).

\section{Jokowi dan Blusukan}

Jokowi lahir di Surakarta. Setelah memimpin Kota Solo selama masa jabatan 2005-2010 Jokowi memutuskan untuk kembali maju pada Pilkada berikutnya, lalu memperoleh kemenangan kembali. Setelah memenangkan pemilihan, pada tahun 2012, menjelang Pilkada DKI Jakarta, ia banyak yang mendorong untuk maju sebagai calon Gubernur DKI Jakarta Periode 2012-2017.

Jokowi kemudian diputuskan maju sebagai calon Gubernur DKI Jakarta dari PDI Perjuangan berpasangan dengan Basuki Tjahaja Purnama (Ahok) dari Gerindra, bersaing dengan 5 pasangan calon gubernur-wakil gubernur yang lainnya. Dalam pemilihan, Pasangan JokowiAhok meraih 42,6 persen, pasangan Fauzi Bowo-Nachrowi Ramli 34,05\% suara, pasangan Hendardji Soepandji-Ahmad Riza Ramli 1,98\% suara, pasangan Hidayat Nurwahid-Didiek J. Rachbini 11,72\% suara, pasangan Faisal BasriBiem Benjamin 4,98\% suara dan pasangan Alex Noerdin-Nono Sampono 4,67\% suara.

Karena belum ada pasangan yang meraih $50 \%+1$ suara yang sah, Pilkada DKI Jakarta dilanjutkan dengan pemilihan putaran kedua yang mempertemukan pasangan Jokowi-Ahok dengan pasangan Fauzi-Nara meraih 46,18\% dari suara yang sah. Dan, akhirnya pada 29
September 2012, KPUD DKI Jakarta menetapkan pasangan Jokowi-Ahok sebagai Gubernur dan Wakil Gubernur DKI untuk masa Bakti 2012-2017, (Nur Ibad Ms, 2015: 12).

Hiruk-pikuk Pilkada DKI Jakarta di tengah pesatnya perkembangan teknologi informasi global, membuat Jokowi semakin populer. Namanya semakin dikenal luas di seluruh Indonesia dan dunia. Rekam jejak kepemimpinannya selama menjadi Walikota Surakarta yang baik, dan pendekatan yang membumi dan pragmatis, seperti yang ditunjukkan melalui program "blusukan" untuk memeriksa keadaan di lapangan secara langsung telah membuat namanya mendunia. Gaya blusukan menjadi bahan pembicaraan di manamana. Membuat penasaran para politisi dan pelaku pemerintahan di berbagai negara, serta pengamat politik di dalam negeri. Gaya kerja blusukan Jokowi, yang apa adanya, spontan, dan non-protokoler selalu ditunggu-tunggu publik. menjadi gaya kepemimpinan baru yang meruntuhkan popularitas gaya kepemimpinan pemimpin-pemimpin sebelumnya selama Indonesia merdeka, (Nur Ibad Ms., 2015: 12).

\section{Blusukan Jokowi sebagai Kampanye Politik}

Jokowi dengan gaya kepemimpinannya yang pragmatis dan membumi. Ia melepaskan semua yang berbau protokoler sebagai pejabat publik dan membaur dengan rakyat, melalui blusukan, sehingga dalam posisi komunikasi yang setara. Gaya kepemimpinan Jokowi ini mendapatkan julukan sebagai demokrasi jalanan dari majalah internasional, The New York Times, (Nur Ibad Ms, 2015: 17).

Blusukan ini termasuk metode intervensi sosial digunakan sebagai strategi kampanye yang dipilih Jokowi adalah langsung turun ke pusat konsentrasi publik yaitu pasar-pasar tradisional dan membaur. Kata kuncinya adalah membaur. Walaupun banyak calon gubernur dan calon wakil gubernur melakukan kunjungan ke pasar, namun mereka tetap menempatkan diri dan berperilaku sebagai pejabat. Sehingga citra yang terbangun ada jarak antara rakyat dan para calon tersebut. Berbeda halnya dengan Jokowi justru menyatu menjadi bagian dari publik. Hal ini menjadi satu nilai (value) berharga, Jokowi membangun citra diri sebagai sosok sederhana, (Wawan Fahrudin dan Ardi Nuswantoro, 2012: 49).

Apa yang dilakukan oleh Jokowi berdasarkan laporan utama Majalah Tempo, edisi 16 Juli 2012 bertajuk "Ronde 2 DKI-1" menunjukkan bagaimana pendekatan tatap muka langsung dengan massa rakyat telah mampu menarik simpati langsung rakyat, (M. 
Sudarsono, 2012: 126). Setelah mempelajari mengenai uraian terkait Jokowi dan Blusikan, maka dibawah ini akan dijelaskan mengenai seperti apa sih pelaksanaan strategi kampanye politik Jokowi melalui Blusukan, uraiannya sebagai berikut.

\section{Blusukan dan Faktor Kemenangan}

Ketika PDI Perjuangan memilih Jokowi, tak bisa dilepaskan dari popularitas Jokowi di Solo tidak hanya didasarkan pada keberhasilannya meraih dua kali jabatan sebagai walikota Solo, tetapi juga kedekatannya dengan rakyat. Menurut Informan penulis, yakni Eddy yang merupakan Ketua RW 01 Kemayoran, Jakarta Pusat, bahwa Jokowi seorang eksekutor yang handal dan visioner, disamping juga karena Keberhasilan Jokowi sebagai Walikota Solo dan Jokowi Kader PDI Perjuangan yang dianggap anak ideologis dari Bung Karno, (Hasil Wawancara Eddy, 2019).

Yang melandasi faktor kemenangan Jokowi adalah banyak faktor, jika dilihat berdasarkan asumsi temuan di lapangan, seperti: pertama, kekecewaan banyak masyarakat di DKI Jakarta atas perilaku banyaknya oknum Aparatur Sipil Negara (ASN) DKI Jakarta yang tidak profesional. Kedua, banyaknya relawanrelawan mandiri yang terdiri dari berbagai macam profesi yang mengharapkan adanya perubahan seperti pelayanan kesehatan dan pegawai honorer/ASN DKI Jakarta yang profesional. Ketiga, primodial dari masyarakat etnis Jawa dan Tionghoa yang ada di DKI Jakarta, dan Keempat, "mesin" partai dari kedua partai yakni PDI Perjuangan dan Gerindra yang bekerja cukup baik.

Di samping itu, bahwa citra Jokowi di masyarakat berdasarkan konstruksi media memang diakui beragam karena ada media yang fair dalam pemberitaan dan ada iklan-iklan pencitraan dari kedua belah pihak melalui media. Tetapi, Jokowi dapat dianggap sebagai media darling yang menarik diliput oleh media, karena kampanye blusukannya. Diakui oleh Eddy bahwa, "Blusukan dianggap adalah cara yang efektif untuk berinteraksi dengan masyarakat di berbagai wilayah," (Hasil Wawancara Eddy, 2019).

Tak dipungkiri bahwa publik menjadi sangat mengenal sosok Jokowi yang diberitakan melalui media massa dan diperbincangkan melalui media sosial. Pengenalan terhadap Jokowi ini telah mencapai tingkat pengenalan yang tinggi. Hal ini ditambah dengan gaya blusukan Jokowi yang dianggap menjadikan kepopuleran Jokowi semakin dikenal secara langsung oleh pemilih. Jokowi dianggap sebagai pemimpin politik yang paling banyak melakukan kontak langsung dengan pemilih Jakarta.

Pengenalan terhadap sosok yang populer dan dianggap mewakili identitas pemimpin ini tentu saja mampu membentuk dukungan pemilih. Dukungan tersebut akan mendorong pemilih untuk lebih jauh terlibat dalam berbagai kegiatan bersama dengan kepopuleran Jokowi tersebut. Elektabilitas yang dimiliki oleh Jokowi ini sebagai pemimpin politik tentu saja merupakan prakondisi munculnya partisipasi pemilih untuk terlibat dalam organisasi (baca: partai politik atau organisasi masyarakat) yang terkait dengan kepopuleran pemimpin politik dan/atau kegiatan kampanye untuk sosok calon kandidat tersebut, (Ummi Salamah, 2015: 163).

Dalam Pilkada DKI Jakarta lalu, bahwa Jokowi tak bisa dinafikkan rajin mengunjungi wong cilik di kampung-kampung kumuh, misalnya, Jakarta Pusat dengan dua lokasi titiknya (Kelurahan Cempaka Baru dan Kelurahan Serdang) menjadi lokasi tempat Jokowi menemui masyarakat dalam Pilkada DKI Jakarta 2012 lalu. Misal, saat Jokowi melakukan kampanye menemui masyarakat, di Kelurahan Cempaka Baru, Kemayoran, Jakarta Pusat, Senin 25 Juni 2012. Ia masuk gang-gang sempit selebar 3 meter di kawasan permukiman padat di Gang RT 7 Nomor 1 di Kelurahan Cempaka Baru, Kemayoran, Jakarta Pusat. Di gang sempit itu Jokowi terhenti di sejumlah rumah penduduk dan berdialog dengan warga, sambil menjelaskan program unggulannya, Kartu Sehat dan Kartu Pintar. Tak pelak, gang padat itu pun penuh sesak dengan orang yang berniat melihatnya berkampanye, (Tempo.co).

Jokowi memang dianggap cukup jeli dan mampu menarik simpati publik Jakarta dengan janji-janji yang realistis dan tidak sulit diwujudkan misalnya, gagasan "Kartu Jakarta Sehat" dan "Kartu Jakarta Pintar" untuk penduduk yang tidak mampu berobat ke rumah sakit dan tidak berkemampuan sekolah. Kedua layanan ini sebetulnya bukan hal baru, namun Jokowi mampu melakukan modifikasi dan terobosan inovatif dari pelayanan kesehatan semisal Jaminan Pelayan Kesehatan Keluarga Miskin (JPK Gakin) dan Jaminan Kesehatan Daerah (Jamkesda) yang sarat alur birokrasi. Apalagi kedua strategi Jokowi ini terbukti efektif di Solo, dan ini menjadi Kartu Sukses Jokowi dan membuat keyakinan publik Jokowi menguat kepada Jokowi, (Wawan Fahrudin dan Ardi Nuswantoro, 2012: 36-37).

Pengakuan akan kampanye Blusukan oleh Jokowi di Cempaka Baru, dijelaskan oleh Asep Mulyaman yang saat itu sebagai Lurah 
Cempaka Baru (sekarang jabatannya camat), Kemayoran, Jakarta Pusat, bahwa "Pas kampanye Jokowi tahun 2012, saat saya masih menjadi lurah di Cempaka Baru bahwa saya tidak masalah adanya calon gubernur yang datang di wilayah ini, malah itu adalah segi positif." Lebih lanjut, Asep Mulyaman menjelaskan bahwa, "Pas pilkada DKI Jakarta 2012, pak Jokowi hadir, dan saat itu sebagai lurah di Cempaka Baru melihat bahwa kampanye dengan cara blusukannya kondusif," (Hasil Wawancara Asep Mulyaman, 2019).

Meski asumsi-asumsi kemenangan itu tak bisa dinafikkan, tetapi Strategi kampanye pasangan Jokowi-Ahok pada Pilkada DKI Jakarta 2012 yang mana kedua orang pasangan itu bukan warga DKI Jakarta, ini menunjukkan suatu fenomenal tersendiri dan juga strategi kampanye politik secara blusukan dirasakan cukup berhasil seperti dikatakan oleh Eddy bahwa, "Jokowi-Ahok langsung terjun ke kantong-kantong relawan dan tokoh-tokoh masyarakat di lapangan. Dan, Jokowi dan team melakukan kunjungan ke kampung-kampung dan Ahok menemani konstituennya di pusatpusat perdagangan, (Hasil Wawancara Eddy, 2019).”

Dalam perspektif marketing politik, layaknya konsumen ekonomi, publik DKI Jakarta merupakan konsumen politik yang perlu dipersuasi untuk memberikan dukungan kepada calon pemimpin daerah di hari pemilihan. Jokowi tampil dengan image kesederhanaan yang memihak wong cilik melalui strategi penyapaan ke pasar-pasar tradisional, kantongkantong kemiskinan dengan membaur 'menjadi mereka.'

Jokowi paham betul bahwa demokrasi pilihan langsung melalui Pilkada membuat faktor figur menjadi daya tarik sangat kuat. Faktor personal Jokowi ini begitu kuat sehingga publik cenderung menaruh kepercayaan pada sosok Jokowi untuk dapat memberikan harapan perubahan bagi Jakarta. Sehingga demikian, pilkada langsung telah menciptakan 'pasar politik' yang mengharuskan politisi yang berkeinginan menjadi pemimpin daerah untuk memiliki pemahaman mengenai pemilih dan 'pasar' tempat para pemilih berada. Tidak ada jalan lain yang efektif kecuali metode blusukan (keluar masuk - bahasa Jawa) Jokowi ke pasarpasar dan kantong-kantong pemukim padat di Jakarta, (Ummi Salamah, 2015: 37-38).

Strategi Jokowi-Ahok dengan cara blusukan yang menghasilkan kemenangan itu dilakukan di tengah situasi bahwa pasangan Jokowi-Ahok diprediksi tidak bisa memenangkan Pilkada DKI Jakarta 2012. Bagi
Eddy, hasil survei seperti "melupakan massa mengambang atau pemilih yang belum memutuskan pilihan, ini tidak diperhitungkan oleh team survei dan team lawan. Ini terjadi karena saat itu pertarungan begitu sengit, ditenggarai bahwa team lawan menyebarkan isu Suku, Agama, Ras, dan Antargolongan sehingga membuat banyak pemilih Jokowi-Ahok diam (silent veto)," (Hasil Wawancara Eddy, 2019).

Dalam permasalahan penelitian ini adalah menekankan pada kampanye politik secara blusukan. Blusukan Jokowi dianggap fenomenal, hal ini pun diakui oleh Eddy bahwa, "Blusukan sangat tepat dilakukan untuk mendapatkan informasi yang aktual sebelum dilakukan eksekusi," (Hasil Wawancara Eddy, 2019).

Komunikasi "blusukan" ini jika merujuk terhadap teori yang digunakan dalam penelitian ini bahwa perwujudan adanya prinsip kebersamaan tanpa beda status "manunggaling kawula gusti," yang dalam perspektif Barat disebut "walking in the shoes of the public." Melalui blusukan, bisa melalui gethok tular (word of mouth communication) secara langsung informasi bisa didapatkan dan meminimalkan salah persepsi. Selain itu, blusukan juga bisa menyetop rumor yang memang tersebar cepat melalui gethok tular dari (mulut) orang ke (mulut) orang. Upaya gethok tular ini penting untuk menangkal rumor berdasarkan prinsip "lawanlah informasi dengan informasi, (ub.ac.id).

Dalam bekerjasama untuk meraih suara agar memenangkan pemilihan, menurut Eddy bahwa, "Jokowi-Ahok melakukan kerja sama dengan baik dalam berbagai tugas. Jokowi mendapatkan data yang aktual di lapangan juga men-check progres atas kemajuan dari suatu proyek pekerjaan dan membuat aparatur di bawah (subordinat) ikut bekerja dengan baik dan sangat efektif," (Hasil Wawancara Eddy, 2019).

Eddy pun menjelaskan bahwa, berdasarkan pengalamannya di Kemayoran, Jakarta Pusat yang merupakan lokus dari penelitian ini. Cara menggalangkan kemenangan yang dilakukan oleh pasangan Jokowi-Ahok yakni kerja team sukses dalam melakukan kampanye khususnya di Kemayoran, Jakarta Pusat; melakukan diskusi dengan para relawan dan masyarakat yang tidak tahu tentang Jokowi dengan cara membaca bulletin dan kliping, juga menonton dalam bentuk Compact Disk melalui televisi tentang keberhasilan Jokowi sebagai Walikota Solo. Melakukan pendekatan kepada tokoh masyarakat yang simpatik kepada Jokowi dan mendirikan pos-pos relawan. Melakukan 
sosialisasi kepada massa mengambang yang kelihatan belum menentukan pilihan.

Di samping itu, bahwa sisi kampanye door to door yakni melalui blusukan. Yang membawa keuntungan bahwa calon dapat langsung menyampaikan program kepada masyarakat. Sisi negatif dapat menimbulkan gesekan antara masyarakat dan penolakan kepada calon oleh masyarakat bukan pendukung (tanpa etika). Oleh karena itu, Tim Jokowi dalam mengerek popularitas mereka untuk memenangkan Pilkada. Tim Sukses Jokowi menentukan titik mana saja yang menjadi basis lawan, disamping juga tim Jokowi mengidentifikasi wilayah-wilayah berdasarkan kelurahan dengan pemilih terbanyak, (Hasil Wawancara Eddy, 2019).

Sedangkan, menurut Suyatin yang merupakan tokoh masyarakat di Kemayoran, mengenai pendapatnya mengenai strategi blusukan sebagai kampanye hal mana poin positif dan negatifnya, dijelaskan bahwa, "Dari segi positifnya bahwa Jokowi merupakan calon pemimpin yang betul-betul ingin mengerti bagaimana kondisi rakyat kecil yang sebenarnya, sehingga nantinya semua kebijaksanaannya akan tepat pada sasarannya. Sedangkan sisi negatifnya karena banyak rakyat yang tidak memahami akan kebijaksanaannya justru menilai sebaliknya, yang terjadi adalah caci makian, atau curhat, dan sok merakyat," (Hasil Wawancara Suryatin, 2019).

Sedangkan menurut Suwarto yang merupakan Ketua Rt 011/RW 09, Cempaka Baru, Jakarta Selatan, bahwa, "Calonnya saat itu yakni Jokowi merakyat, ia mau berbaur dengan masyarakat, tidak seperti pejabat yang selama ini terlihat oleh masyarakat, sehingga menimbulkan simpati. Sedangkan poin negatifnya, banyak masyarakat yang masih kurang merasakan janji kampanye," (Hasil Wawancara, Suwarto, 2019).

Kemudian, juga dipetakan lagi wilayah dengan rata-rata jumlah anggota keluarga 4-6 orang terbanyak. Tim juga menggolongkan daerah dengan jumlah golput terbanyak, miskin, bersuku Jawa, dan beragama Islam. Dengan aneka kriteria itu, misal, tim menentukan 77 dari 267 kelurahan yang harus didatangi Jokowi dan Ahok pada masa kampanye. Lalu juga disusun penentuan materi kampanye yang telah disesuaikan dengan masalah setiap daerah. Seperti di kelurahan miskin, Jokowi berkampanye soal asuransi kesehatan dan pendidikan, yang sukses di Solo. Juga ia memperkenalkan, seperti di Kemayoran kartu sehat dan kartu pintar, (Sudarsono, 2012: 128).
Jadi, menurut Eddy, bahwa blusukan yang dilakukan oleh Jokowi bukan merupakan pencitraan politik, karena dengan blusukan maka Jokowi secara otomatis menggerakkan subordinat atau aparatur di bawahnya untuk bekerja profesional sehingga mendapatkan hasil yang benar dan bermanfaat bagi kebutuhan masyarakat. Dan, dapat dikatakan bahwa terpilihnya Jokowi sebagai Gubernur karena masyarakat tertarik dengan visi-misi yang ditawarkan oleh Jokowi-Ahok secara langsung dalam kampanye blusukan dan juga citra Jokowi sebagai walikota solo yang berhasil, (Hasil Wawancara Eddy, 2019).

Kedekatan Jokowi sebagai pemimpin dengan Masyarakat dengan gaya blusukannya, telah mulai dibangun sejak kepemimpinannya di Solo, Jawa Tengah, yang dianggap berhasil dan kemudian ditunjukkannya selama masa kampanye di Jakarta, sehingga telah berhasil membangkitkan harapan warga DKI Jakarta akan munculnya pemimpin yang berjiwa demokratis dan mengayomi kepentingan warganya hingga paling bawah.

Dengan pendekatan personal yang mendahulukan dialog untuk mendengarkan aspirasi dari bawah, kebijakan yang dikeluarkan Jokowi minim penolakan. Berbagai silang pendapat dan kepentingan juga dapat diakomodasi. Inilah yang dilakukan oleh Jokowi melalui blusukannya, menjelaskan programnya, dan berdialog, bahkan blusukan Jokowi (secara tidak langsung) adalah program kebijakan Jokowi itu sendiri yang ingin melibatkan warga dalam menentukan kebijakan atau tindakan penyelesaian, sehingga ketika kebijakan itu diterapkan warga akan sudah mengetahuinya dan menerima dengan kesadarannya.

Gaya blusukan dan citra yang dimiliki Jokowi berkaitan erat, citra yang dibangun Jokowi adalah kesederhanaan dan kedekatannya dengan rakyat. Sehingga, Jokowi dengan mudah keluar masuk daerah kantong-kantong suara, kantong-kantong kemiskinan DKI Jakarta, dan sebagainya. Jadi, dari penelitian ini dapat ditarik kesimpulan bahwa kedekatan Jokowi sebagai pemimpin dengan Masyarakat melalui gaya blusukannya, inilah yang membuat namanya melesat dan hal itu menjadikan gaya blusukannya sebagai bagian dari kampanyenya untuk menjelaskan program kerja yang akan ditawarkan ketika terpilih di Pilkada DKI Jakarta 2012 lalu, hal mana blusukan yang telah menjadi strategi kampanye Jokowi terbukti berhasil dengan terpilihnya Jokowi-Ahok di Pilkada DKI Jakarta 2012 lalu, meski pasangan Jokowi-Ahok ditengarai akan kalah dalam Pilkada, namun realitasnya pasangan ini 
memenangkan Pilkada DKI Jakarta berdasarkan gaya blusukannya dengan cara menawarkan program kerja melalui komunikasi langsung dengan masyarakat/pemilih.

\section{PENUTUP}

Berdasarkan hasil penelitian dan pembahasan dapat disimpulkan bahwa keberhasilan Jokowi dalam memimpin sebagai walikota Solo telah memperlihatkan sosok Jokowi dianggap sebagai seorang pemimpin yang dekat dengan rakyat melalui blusukan. Ketika Jokowi mencalonkan diri sebagai Gubernur DKI, maka Jokowi telah menggunakan pendekatan sebagai pemimpin yang suka blusukan karena sering masuk ke tempat perkampungan yang padat dengan ganggang yang kumuh hingga ke gorong-gorong untuk mengecek dan mengetahui sesuatu. Jokowi melalui blusukannya, mengupayakan sebuah kampanye politik dengan menjelaskan programnya, dan berdialog, bahkan blusukan Jokowi (secara tidak langsung) adalah program kebijakan Jokowi itu sendiri yang ingin melibatkan warga dalam menentukan kebijakan atau tindakan penyelesaian, sehingga ketika kebijakan itu diterapkan warga akan sudah mengetahuinya dan menerima dengan kesadarannya.

Kampanye door to door yakni melalui blusukan. Juga tak bisa dilepaskan dari hasil positif dan negatif, bahwa hasil positif adalah pertama, membawa keuntungan bahwa calon dapat langsung menyampaikan program kepada masyarakat; kedua, Jokowi merupakan calon pemimpin yang betul-betul ingin mengerti bagaimana kondisi rakyat kecil yang sebenarnya, sehingga nantinya semua kebijaksanaannya akan tepat pada sasarannya; dan ketiga, bahwa calon kandidat itu dirasakan oleh masyarakat mau berbaur dengan masyarakat sehingga menimbulkan simpati dan dukungan rakyat melalui dukungan suara rakyat dalam pemilu tersebut. Tetapi, sisi negatifnya adalah, pertama, cara blusukan dapat menimbulkan gesekan antara masyarakat dan penolakan kepada calon oleh masyarakat bukan pendukung; kedua, sisi negatifnya karena banyak rakyat yang tidak memahami akan kebijaksanaannya justru menilai sebaliknya, bahwa calon kandidat dapat dianggap hanya sok merakyat atau pencitraan semata; dan ketiga, belum tentu pula dengan cara blusukan maka kebijakan yang janjikan sewaktu kampanye akan dihasilkannya dan/atau benar-benar dapat dinikmati oleh masyarakat.
Berdasarkan penelitian ini bahwa menurut penulis, saran yang dapat ditawarkan dalam penelitian ini adalah: pertama, kampanye politik yang dilakukan dengan cara blusukan mendekatkan diri ke masyarakat, dan tepat sasaran. Oleh karena itu, partai politik semestinya dalam pemilu tetap menggunakan kampanye politik tersebut agar antara calon kandidat dan rakyat memiliki hubungan yang selalu dekat. Kedua, kampanye politik dengan cara blusukan ini harus didukung oleh kandidat yang memang dikenal masyarakat dan punya program yang bisa menjawab situasi di masyarakat; dan Ketiga, kampanye politik dengan cara blusukan itu semestinya, jika calon kandidat itu terpilih diharapkan juga dapat dirasakan oleh rakyat melalui hasil komunikasi politik antara calon kandidat terhadap program yang benar-benar dapat diwujudkan dan dianggap mewakili keinginan masyarakat tersebut.

\section{DAFTAR PUSTAKA}

Arikunto, Suharsimi, Prosedur Penelitian Suatu Pendekatan Praktek (Edisi Revisi V), (Jakarta: Rineka Cipta, 2002).

A.Zulkarnain dan Syamsuddin Haris, Fenomena Blusukan dalam Model Kepemimpinan Politik Joko Widodo, Jurnal Politik, Universitas Nasional, Vol. 13, No. 1, 2017, (https://media.neliti.com/media/publication s/126122-ID-fenomena-blusukan-dalammodel-kepemimpin.pdf).

Eko Priliawito, Jokowi Awali Kampanye Sabtu Ini di Pasar Palmerah, (https://www.viva.co.id/berita/metro/3515 28-jokowi-awali-kampanye-di-pasarpalmerah).

Fahrudin, Wawan, dan Nuswantoro, Ardi, Kartu Sukses Jokowi-Ahok Melangkah Pasti Menuju DKI Jakarta 1, (Jakarta: Talenta Makra Publishing, 2012).

Firmanzah, Marketing Politik: Antara Pemahaman dan Realitas, (Jakarta: Yayasan Obor Indonesia, 2007).

-------, Mengelola Partai Politik: Komunikasi dan Positioning Ideologi Politik di Era Demokrasi, (Jakarta: Yayasan Obor Indonesia, 2008)

Ibad Ms, Nurul, Jokowi Dalam Cermin Dunia: Antara Simpati dan Sinisme, (Jakarta: Papas Sinar Sinanti, 2015).

Indradie, Andri, Rakyat Memantau Ibukota Rakyat Memantau Jokowi Basuki, (Jakarta: Grasindo, 2013). 
Muhamad Rizki, Di Kemayoran Jokowi dari Gang Sempit ke Posyandu, (https://www.tempo.co/read/412744/dikemayoran-jokowi-dari-gang-sempit-keposyandu/full\& Paging=Otomatis).

Nursal, Adman, Political Marketing Strategi Memenangkan Pemilu: Sebuah Pendekatan Baru Kampanye Pemilihan DPR, DPD, dan Presiden, (Jakarta: Gramedia, 2002).

Rachmat Kriyantono, Public Relations: Kearifan Jawa Menuju Untuk "Managing by Walking Around," (http://rachmatkriyantono.lecture.ub.ac.id /tag/blusukan/).

Salamah, Ummi, Brand Pemimpin Politik, (Jakarta: Makna Informasi, 2015).

Subiyakto, Henry, dan Ida, Rachmah, Komunikasi Politik, Media, dan Demokrasi, (Jakarta: Kencana, 2014).

Sudarsono, Jokowi Effect: Tanda-tanda Runtuhnya Era Politik Citra, (Surabaya: Stomata, 2012).
Susanto, Astrid S., Komunikasi Sosial di Indonesia, (Bandung: Binacipta, 1985).

Tabroni, Roni, Marketing Politik: Media dan Pencitraan di Era Multipartai, (Jakarta: Graha Ilmu, 2014).

Wahid, Umaimah, Komunikasi Politik: Teori, Konsep, dan Aplikasi pada Era Media Baru, (Bandung: Simbiosa Rekatama Media, 2016).

Wasesa, Silih Agung, Political Personal Branding: Strategi Jitu Menang Kampanye di Era Digital, (Jakarta: Expose, 2018).

Wulandari, Retno, Media Darling Ala Jokowi Menjadi Sosok Yang Disukai Media, (Jakarta: Gramedia, 2014).

Zaenal Muttaqin, Konstruksi Gaya Blusukan, (https://elib.unikom.ac.id/files/ disk1/689/jbptunikompp-gdl-zaenalmutt34401-1-unikom_z-1.pdf). 